\title{
Peningkatan Pengetahuan Mahasiswa Kedokteran Tingkat 3 UPNVJ Dalam Mencegah Stunting
}

\author{
Arfiyanti $^{1}{ }^{1}$, Prasetyo Hadi ${ }^{2}$, Adi Sukrisno ${ }^{3}$, Wendy ${ }^{4}$, Nugrahayu ${ }^{5}$
}

1) Program Studi IImu Kedokteran, FK, Universitas Pembangunan Nasional Veteran Jakarta

2) Program Studi Magister Manajemen, FEB, Universitas Pembangunan Nasional Veteran Jakarta

3) Program Studi Ilmu Kedokteran, FK, Universitas Pembangunan Nasional Veteran Jakarta

4) Program Studi Ilmu Kedokteran, FK, Universitas Pembangunan Nasional Veteran Jakarta

5) Program Studi Ilmu Kedokteran, FK, Universitas Pembangunan Nasional Veteran Jakarta

*e-mail: arfiyanti.ui@gmail.com

\begin{abstract}
Background: In 2020, WHO found that 155 million children with less than 5 years age were stunted. In Indonesia 2019, $27.67 \%$ of the total population suffered stunting. This number was successfully reduced from $37.8 \%$ in 2013. However, this number is still higher than maximum stunting tolerance, set by World Health Organization (WHO), which is less than 20\%. In 2024, Indonesia's stunting case targeted to be reduced at $14 \%$. Preliminary survey conducted on UPNVJ third year's medical students, and found that there was no webinar on stunting and its prevention to increase knowledge of third year's medical students. Objectives: Arrange webinar about stunting and its prevention to improve UPNVJ third year's medical students knowledge. Stunting can be overcome by fulfilling the right nutrition on first 1000 day's of life by early breastfeeding, exclusive breastfeeding for 6 months, complementary feeding from 6-24 months, while continuing breastfeeding for 24 months. Conclusion: Webinar participants consisted of $81 \%$ women and $19 \%$ men. This webinar can increase the knowledge of UPNVJ third year's medical students (78\% pretest and $85 \%$ posttest ). Webinars are $100 \%$ useful for students and need to be a routine for UPNVJ third year's medical students (98\%).
\end{abstract}

Keywords: stunting; malnutrition; prevention; webinar.

\begin{abstract}
Abstrak
Latar Belakang: Data WHO pada tahun 2020 menemukan sedikitnya 155 juta anak di seluruh dunia dengan usia kurang dari 5 tahun mengalami stunting. Di Indonesia, penderita stunting pada tahun 2019 mencapai $27,67 \%$ dari total populasi. Angka itu berhasil ditekan dari 37,8\% pada tahun 2013. Namun, angka ini masih lebih tinggi dibandingkan toleransi maksimal stunting yang ditetapkan Organisasi Kesehatan Dunia (WHO), yaitu kurang dari 20\%. Pada tahun 2024, kasus stunting di Indonesia diharapkan bisa ditekan hingga berada di angka 14\%. Survey pendahuluan yang dilakukan pada mahasiswa kedokteran tingkat 3 UPNVJ ditemukan belum adanya webinar mengenai stunting dan pencegahannya untuk meningkatkan pengetahuan mahasiswa kedokteran tingkat 3. Tujuan: Melaksanakan webinar mengenai stunting dan pencegahannya untuk meningkatkan pengetahuan mahasiswa kedokteran tingkat 3 UPNVJ. Stunting dapat diatasi dengan pemenuhan nutrisi yang tepat 1000 HPK yaitu dengan melakukan menyusui Dini, memberikan ASI eklusif sampai 6 bulan, MPASI mulai 6- 24 bulan, dengan tetap melanjutkan ASI sampai 24 bulan. Kesimpulan Peserta webinar terdiri dari $81 \%$ perempuan dan $19 \%$ laki laki. Pelaksanaan webinar dapat meningkatkan pengetahuan mahasiswa tinggkat 3 kedokteran UPNVJ (pretest $78 \%$ dan posttest $85 \%$ ). Webinar bermanfaat $100 \%$ bagi mahasiswa dan perlu jadi rutinas untuk mahasiswa kedokteran tingkat 3 UPNVJ (98\%).
\end{abstract}

Kata Kunci: stunting; malnutrisi; pencegahan; webinar.

\begin{tabular}{|c|c|c|}
\hline Submitted: $2021-06-22$ & Revised: $2021-07-24$ & Accepted: $2021-07-31$ \\
\hline
\end{tabular}

\section{Pendahuluan}

Stunting merupakan perawakan pendek yang salah satunya disebabkan oleh karena proses kumulatif kekurangan nutrisi (Prendergast and Humphrey, 2014) (Sjarif et al, 2015). Stunting di mulai dari dalam Rahim (11.2\%), antara lahir hingga 2 tahun (60.6\%), dan pada usia 2- 5 tahun (28\%) (Millward, 2017). Seorang anak dikatakan stunting bila tinggi badan menurut usia berdasarkan kurva standar pertumbuhan CDC $2000 \leq 95 \%$ (Wild et al, 2015).

Anak dibawah usia dua tahun sangat rentan tejadi masalah gizi terutama stunting. Kondisi stunting yang terlambat disadari akan mengganggu perkembangan fisik dan kognitif anak, 
keterlambatan perkembangan mental, serta penurunan kualitas belajar di sekolah (Onis et al,2013). Anak dengan stunting juga menunjukan performa pendidikan yang lebih rendah, kemampuan verbal dan IQ rendah (Nahar et al, 2019).

Kekurangan nutrisi pada 1000 HPK dapat juga berpengaruh terhadap morbiditas, mortalitas, serta berhubungan dengan kinerja intelektual dan kesehatan anak secara keseluruhan pada masa remaja hingga dewasa (Kemenkes RI, 2017). Kekurangan mikronutrien pada ibu hamil akan mempengaruhi pertumbuhan dan perkembangan janin serta mempengaruhi masa depan janin menjadi manusia dengan kelainan pada bagian ginjal, fungsi kardiovaskular, pancreas dan fungsi paru-paru (Christian and Stewart, 2010).

Pada fase awal kehidupan, Nutrisi merupakan faktor mendasar bagi pertumbuhan dan perkembangan manusia (UNICEF, 2019). Nutrisi merupakan aspek yang sangat krusial, sejak kehamilan hingga anak berusia dua tahun (1000 HPK) (BAPPENAS, 2020). Asupan nutrisi yang tepat dapat mendukung tumbuh kembang yang maksimal serta perkembangan otak secara pesat, sehingga menghasilkan generasi penerus yang gemilang (UNICEF, 2019). Protein memiliki peranan yang penting dalam perkembangan janin, terutama fungsi neurologisnya (Ji et al, 2017).

Nutrisi yang kurang pada anak di bawah usia 5 tahun diperkirakan meninggal $45 \%$. Pada tahun 2016, terdapat 155 juta anak di seluruh dunia dengan usia kurang dari 5 tahun yang menderita stunting, 47 juta menderita wasting, 41 juta lainnya memiliki berat badan berlebih atau obesitas. Malnutrisi menjadi permasalahan global yang mutlak. Pemberian nutrisi yang tepat, penting untuk menghindari malnutrisi pada anak (WHO, 2020).

Guna mencapai pemenuhan nutrisi yang tepat 1000HPK, perlu dilakukan Inisiasi Menyusui Dini (IMD) setelah bayi lahir minimal selama 1 jam. Berikan Air Susu Ibu (ASI) secara eksklusif dimulai sejak bayi lahir hingga bayi berusia 6 bulan. Pemberian Makanan Pendamping ASI (MPASI) sejak bayi berumur 6 hingga 24 bulan, dengan tetap melanjutkan pemberian ASI hingga anak berusia 24 bulan atau lebih (Kemenkes RI, 2018).

IMD dapat menstimulasi produksi ASI, mengurangi perdarahan pascapartum, menghasilkan antibodi bagi bayi baru lahir dan menentukan keberhasilan pembentukan serta durasi yang lebih lama dalam menyusui. Penelitian menunjukkan bahwa IMD dikaitkan dengan risiko kematian neonatal yang lebih rendah (Takahashi et al, 2017).

Pemberian ASI eksklusif juga terbukti mampu memenuhi kebutuhan nutrisi dan melindungi bayi dari berbagai penyakit infeksi seperti diare, gastroenteritis, infeksi saluran pernapasan akut bagian bawah, dan otitis media (Frank et al, 2019) (NHS, 2020). Durasi pemberian ASI eksklusif mampu menurunkan prevalensi berat badan berlebih dan obesitas pada anak (WHO \& UNICEF, 2017).

ASI dihasilkan oleh sepasang kelenjar payudara ibu pasca melahirkan dan mengandung zat gizi berupa berbagai makronutrien dan mikronutrien yang steril dari mikroorganisme sehingga aman dikonsumsi bayi. Makronutrien yang terdapat dalam ASI meliputi karbohidrat, protein, dan lemak, sementara mikronutrien terdiri dari vitamin dan mineral (kalsium, magnesium, selenium, zinc, fosfor, besi, natrium) (Butts et al, 2018) (Marriott et al, 2020) (Savarino et al, 2021). ASI memiliki berbagai macam vitamin, antara lain vitamin B6, B12, C, A, E, D, dan K (Perrella et al, 2021).

ASI merupakan biofluida spesifik dengan komposisi bervariasi yang berkaitan dengan komponen nutrisi dan bioaktif. Kandungan dalam ASI memberikan bayi nutrisi yang seimbang dan perlindungan terhadap patogen menular (Mosca and Giannì, 2017). ASI juga mengandung non gizi berupa; hormon, faktor kekebalan tubuh, anti alergi, anti inflamasi yang mencukupi seluruh unsur kebutuhan bayi (Ballard and Morrow, 2013).

ASI mengandung $87 \%$ air, $3-5 \%$ lemak, 6,9-7,2\% laktosa, 0,8 - 0,9\% protein, vitamin, mineral, dan substansi bioaktif lainnya (Shah and Alhawaj, 2020). Lemak merupakan sumber kalori utama pada ASI (Keikha et al, 2017). Lemak pada ASI berfungsi untuk regulasi pertumbuhan, 
respon inflamasi, sistem imun, penglihatan, perkembangan kognitif, serta sistem motorik pada bayi. DHA dan asam arakidonat digunakan untuk diferensiasi sel dan perkembangan sinaps sistem saraf bayi (Shah and Alhawaj, 2020). Lemak yang dapat mempengaruhi perkembangan kognitif anak dan proses tumbuh kembang otak berupa asam lemak omega 3 (Khomsan, 2004).

Laktosa dalam ASI akan meningkatkan penyerapan kalsium dan mengalami hidrolisis menjadi glukosa serta galaktosa. Glukosa berfungsi sebagai sumber energi untuk pertumbuhan otak. Galaktosa menjadi sumber produksi galaktolipid kemudian serebrosida yang penting bagi perkembangan otak (Raymond and Morrow, 2020).

Protein pada ASI terdiri atas kasein dan protein whey (laktoserum). ASI juga terdiri dari asam amino esensial, taurin, yang berperan sebagai neuroprotektor dan osmoregulator untuk perkembangan otak (Sánchez et al, 2021).

ASI mengandung $50 \%$ dari total energy yang diperlukan. Pertumbuhan janin yang optimal hanya akan terjadi bila mendapatkan nutrisi yang adekuat. Lipid dari ASI digunakan untuk pertumbuhan dan perkembangan anak. Fungsi ASI untuk meningkatkan system imun, meningkatkan kognitif dan pertumbuhan fisik (Keikha et al, 2017). ASI dapat meningkatkan 4,5 poin IQ pada bayi yang diberi ASI dibandingkan dg yang tidak diberi ASI (Koletzko, 2016) (Gardner et al, 2017).

Keperluan nutrisi saat laktasi sangat tinggi, meningkat $25 \%$ pada saat laktasi. Kebutuhan protein meningkat hingga 54\%. Bayi yang diberi ASI pada umur 6-8 bulan memerlukan zat besi 9 kali lebih banyak dan zinc 4 kali lebih banyak dibanding laki-laki dewasa (Dewey, 2016). Saat 6 bulan pertama kelahiran, ASI merupakan satu satunya sumber nutrisi anak (Young et al, 2018.) Status nutrisi ibu mempengaruhi kualitas dari ASI sehingga dapat mempengaruhi pertumbuhan janin (Allen, 2012). Gizi buruk ibu merupakan determinan penting terhadap pertumbuhan janin dan stunting (Young et al, 2018). Ketika ibu memiliki asupan mikronutrien yang inadekuat maka dapat menyebabkan kualitas ASI yang menurun (Allen, 2012). Kandungan protein dalam ASI pada awal menyusui berkisar 1,4-1,6 g / $100 \mathrm{~mL}$. Setelah tiga hingga empat bulan menyusui 0,8-1,0 g / 100 $\mathrm{mL}$. Setelah enam bulan 0,7-0,8 g / $100 \mathrm{~mL}$ (Castle, Paula. 2010). Pada usia bayi 6 bulan, terjadi peningkatan kebutuhan kalori, protein, seng, zat besi dan vitamin larut lemak ( vitamin A, D, K), yang diperlukan untuk pertumbuhan adekuat (Alvisi et al, 2015).

Setelah usia 6 bulan, produksi ASI dan volume jaringan payudara akan menurun (Jacqueline Kent, 2015). Menurut WHO makanan pendamping diperlukan, ketika ASI tidak memenuhi kebutuhan nutrisi bayi, sehingga dibutuhkan makanan dan minuman lain bersamaan dengan ASI (Fewtrell et al, 2017). Bayi setelah usia 6 bulan harus mendapat MPASI untuk mencukupi kebutuhannya. Kualitas MPASI seringkali tidak memadai, terutama dalam hal energi, protein, dan mikronutrien (Lestari et al, 2005). Pemberian makanan pendamping yang tidak adekuat akan menyebabkan stunting (Beal et al, 2018). Sejak usia 6 bulan ASI saja sudah tidak dapat mencukupi kebutuhan energi, protein, zat besi, vitamin $D$, seng, vitamin A sehingga diperlukan Makanan Pendamping ASI (MPASI) yang dapat melengkapi kekurangan zat gizi makro, mikronutrien dan sambil melanjutkan ASI sampai usia bayi 24 bulan. Kekurangan zat gizi yang terdapat di ASI perlu dipenuhi oleh MPASI (Dewey, 2001). MPASI juga mengandung ligan untuk mencegah interaksi antar mikronutrien sewaktu diserap di usus. Total kebutuhan nutrisi yang digunakan di Indonesia didasari PERMENKES RI NO. 28 TH 2019, Tentang Angka Kecukupan Gizi yang dianjurkan bagi Bangsa Indonesia. Kebutuhan Nutrisi untuk anak juga direkomendasikan ikatan dokter anak Indonesia (IDAI, 2015).

Pemberian MPASI merupakan masa krusial untuk mencegah malnutrisi pada anak termasuk stunting, wasting, defisiensi mikronutrien, obesitas, dan penyakit tidak menular yang berkaitan dengan pola makan (UNICEF, 2020). MPASI dapat mulai diberikan pada: anak mampu duduk dengan leher tegak serta mengangkat kepala tanpa membutuhkan bantuan, anak memperlihatkan ketertarikan terhadap makanan seperti berusaha menggapai makanan yang berada di hadapannya, 
anak mudah lapar dan sering memperlihatkan tanda lapar meskipun ASI telah diberikan dengan rutin (IDAI, 2018).

Pemberian MPASI yang tepat dapat memberikan banyak manfaat; melengkapi sumber nutrisi bayi (Kemenkes, 2018), menyokong tumbuh kembang bayi (Irfan, 2019), membimbing bayi dalam mengenali dan mengonsumsi makanan selain ASI yang dibutuhkan untuk memenuhi kebutuhan nutrisinya (Kemenkes, 2018), mengurangi risiko infeksi (Fewtrell et al, 2017) , mengembangkan kemampuan bayi dalam mengunyah serta menelan makanan (Kemenkes, 2018), mengurangi risiko alergi (West, 2017), membantu perkembangan saraf (Campoy et a., 2018), membantu pembentukan mikrobiota saluran pencernaan (Campoy et al, 2018).

MPASI diberikan saat bayi berusia 6 bulan, dimulai dengan pengenalan makanan lunak, setengah padat, kemudian padat. Waktu pemberian pertama MPASI merupakan hal yang penting saat ASI eksklusif tidak lagi cukup untuk memenuhi kebutuhan nutrisi bagi tumbuh kembang anak (UNICEF, 2020).

Frekuensi pemberian MPASI harus meningkat seiring bertambahnya usia : Untuk bayi dengan usia $6-8$ bulan diberikan ASI dan dianjurkan untuk memberikan makanan lunak, setengah padat, atau padat sebanyak dua kali dalam sehari. Untuk bayi dengan usia $9-23$ bulan yang diberikan ASI dan dianjurkan untuk memberikan makanan lunak, setengah padat, atau padat sebanyak tiga kali dalam sehari (UNICEF, 2020).

Konsistensi MPASI perlu disesuaikan secara bertahap, dimulai dari lunak, setengah padat, hingga padat sesuai usia bayi (UNICEF, 2020). Rekomendasi terkait konsistensi MPASI bayi berusia 6 bulan halus hingga menjadi bubur kental (pure). Bayi berusia $6-9$ bulan memiliki tekstur halus (puree) atau makanan yang dilumatkan (mashed). Bayi berusia $9-12$ bulan makanan yang dicincang secara halus (minced), kasar (chopped), ataupun makanan ringan yang bisa dipegang oleh bayi (finger foods) mulai dapat diberikan. Bayi berusia $12-24$ bulan, dapat diberikan makanan yang dikonsumsi oleh keluarga (dihaluskan atau dicincang sesuai kebutuhan) (IDAI, 2018)

MPASI yang diberikan secara beragam dapat memenuhi kebutuhan nutrisi dan mengenalkan berbagai rasa maupun tekstur kepada bayi. Variasi yang diberikan dapat dimulai dari karbohidrat, kacang-kacangan, susu, daging, telur, sayur dan buah (UNICEF, 2020). Pemberian MPASI perlu dilakukan secara responsif dengan melihat tanda saat anak lapar atau kenyang dan memberikan respon sesuai dengan kebutuhan anak (UNICEF, 2020). MPASI perlu dipersiapkan, disimpan, dan diberikan secara higienis. Makanan yang diberikan kepada bayi perlu dipastikan terbebas dari patogen, racun, dan bahan kimia berbahaya (UNICEF, 2020).

Porsi MPASI perlu diawali dengan jumlah yang sedikit kemudian ditambahkan secara bertahap seiring bertambahnya usia. Untuk bayi usia $6-8$ bulan, pemberian MPASI dimulai dengan $2-3$ sendok teh makanan kemudian beralih menjadi $125 \mathrm{ml}$ setiap kali makan. Untuk bayi dengan usia 9 - 11 bulan, dapat diberikan $125 \mathrm{ml}$ setiap kali makan. Untuk bayi dengan usia $12-$ 23 bulan, dapat diberikan 187,5 - $250 \mathrm{ml}$ setiap kali makan (UNICEF, 2020).

\section{Metode}

Berdasarkan analisis situasi dan hasil survey pendahuluan yang dilakukan, permasalahan yang dihadapi mitra adalah belum pernah diadakan webinar mengenai stunting dan pencegahannya untuk meningkatkan pengetahuan mahasisiwa kedokteran tingkat 3 UPNVJ. Pengetahuan yang di dapat, bisa dipraktekan dilayanan kesehatan ibu dan anak. Tim Pengabdian Kepada Masyarakat Fakultas Kedokteran Univesitas Pembangunan Nasional Veteran Jakarta bermaksud untuk melakukan webinar kepada mahasiswa tingkat 3 dengan topik stunting dan pencegahannya. Secara institusional FKUPNVJ memiliki kinerja yang sangat baik di dalam 
menjalankan program kompetitif bidang pengabdian kepada masyarakat. FKUPNVJ memiliki para ahli di bidang dan disiplin ilmu yang berkaitan dengan kesehatan.

Pada pelaksanaan kegiatan PKM ini, langkah pertama, tim Pengabdian Masyarakat Fakultas Kedokteran UPNVJ melakukan pengkajian dengan survey awal ke mahasiswa kedokteran tingkat 3 UPNVJ. Berdasarkan survey tersebut didapatkan beberapa permasalahan yang dihadapi.

Langkah kedua, menyiapkan materi kegiatan PKM mengenai stunting dan pencegahannya, membuat soal untuk pretest dan posttest. Menyiapkan program untuk menilai hasil pretes posttest secara cepat sehingga bisa digunakan untuk mendapatkan nilai mahasiswa yang paling tinggi untuk diberi hadiah.

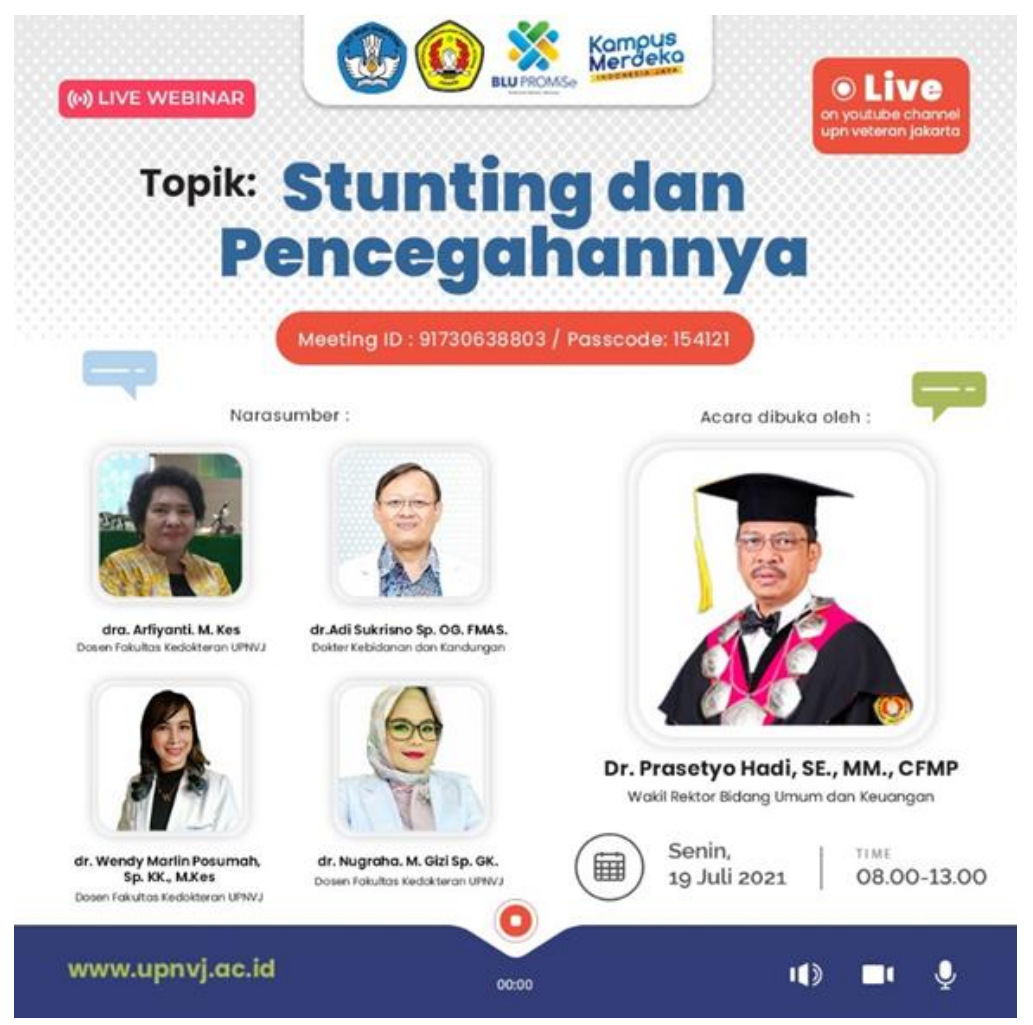

Gambar 1. Narasumber webinar

Langkah ketiga melaksanakan webinar. Bapak Dr.Prasetyo Hadi, SE.,MM.,,CFMP selaku wakil Rektor II memberikan sambutan dalam webinar senin 19 Juli 2021. Narasumber merupakan dosen kedokteran UPNVJ yaitu dr. Adi Sukrisno,Sp.OG.FMAS., Dra.Arfiyanti,M.Kes, Dr.Nugrahayu Widyawardani, M.Gizi, SpGK., dr.Wendy, Sp.KK.M.Kes.

Tim pengabdian memberikan pretest sebelum presentasi dan posttest setelah prsentasi dari setiap nara sumber. Evaluasi dilakukan untuk mengetahui sejauh mana efektivitas webinar ini untuk mencapai tujuan kegiatan yang telah dicanangkan. Adapun aspek yang dievaluasi meliputi : efektvitas pelaksanaan dilihat dari : manfaat webinar, tingkat pengetahuan dan pemahaman serta efektivitas webinar,apakah perlu webinar dilaksanakan secara ruti. Perubahan tingkat pengetahuan mahasiswa kedokteran tingkat 3 UPNVJ dilihat dari nilai pre dan pos tes.

\section{Hasil dan Pembahasan}

Webinar dilaksanakan sesuai jadwal yaitu hari senin 19 juli 2021 pukul 8.30 - 13.00. Bapak Dr.Prasetyo Hadi, SE.,MM.,CFMP selaku wakil Rektor II memberikan sambutan dalam webinar ini. 
Webinar menggunakan media power point supaya mahasiswa mudah memahami materi yang diterangkan. Webinar dengan 4 narasumber berjalan lancar. Narasumber merupakan dosen kedokteran UPNVJ yaitu dr. Adi Sukrisno,Sp.OG.FMAS.; Dra.Arfiyanti,M.Kes; Dr.Nugrahayu Widyawardani, M.Gizi, SpGK.; dr.Wendy, Sp.KK.M.Kes. yang dapat dilihat pada gambar 1. di bawah ini. Secara institusional FKUPNVJ memiliki kinerja yang sangat baik di dalam menjalankan program kompetitif bidang pengabdian kepada masyarakat. FKUPNVJ memiliki para ahli di bidang dan disiplin ilmu yang berkaitan dengan kesehatan.

Peserta webinar adalah mahasiswa kedokteran tingkat 3 UPNVJ. Peserta webinar sebagian besar perempuan ( $81 \%$ ) dan $19 \%$ laki laki.\%tase jenis kelamin peserta webinar dapat dilihat pada gambar 2.

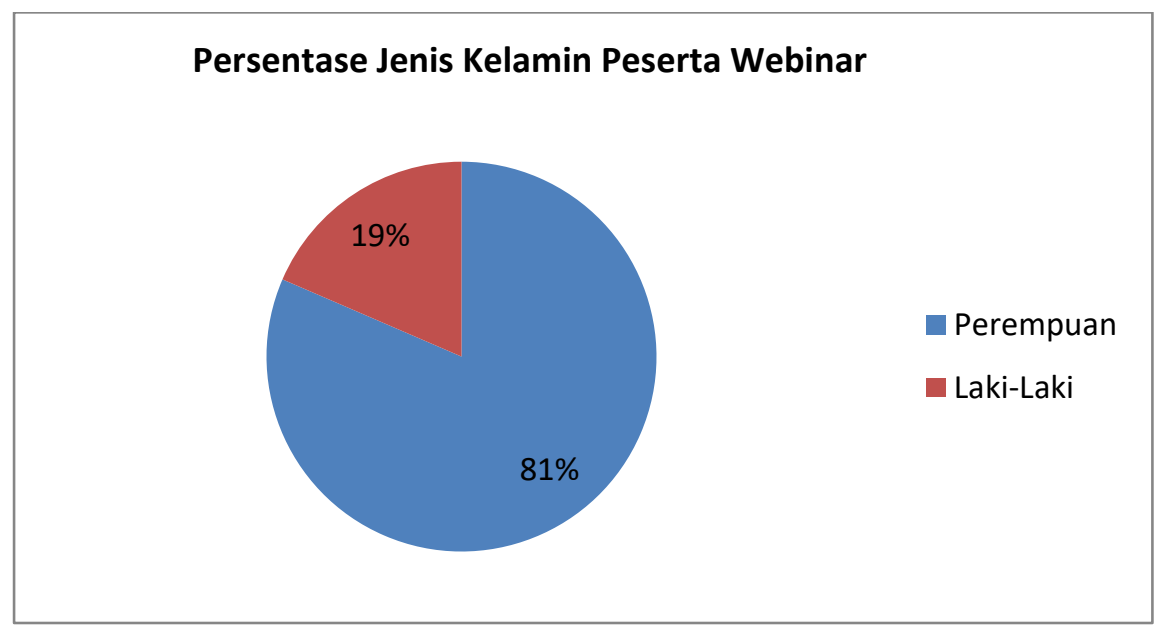

Gambar 2. Jenis kelamin peserta webinar

Data WHO pada tahun 2020 menemukan sedikitnya 155 juta anak di seluruh dunia dengan usia kurang dari 5 tahun mengalami stunting. Di Indonesia, penderita stunting pada tahun 2019 mencapai $27,67 \%$ dari total populasi. Angka itu berhasil ditekan dari 37,8\% pada tahun 2013. Namun, angka ini masih lebih tinggi dibandingkan toleransi maksimal stunting yang ditetapkan Organisasi Kesehatan Dunia (WHO), yaitu kurang dari 20\%. Posisi Indonesia masih berada di urutan keempat dunia dan urutan kedua di AsiaTenggara terkait kasus balita stunting. Presiden Joko Widodo pada Januari 2021 menargetkan pada tahun 2024 kasus stunting di Indonesia bisa ditekan hingga berada di angka $14 \%$.

Webinar bermanfaat bagi mahasiswa kedokteran dan bisa dipraktekan di layanan kesehatan ibu dan anak sehingga bisa menekan kasus stunting nantinya. Kebermanfaatan webinar $100 \%$ seperti yang terlihat dalam gambar 3 .

Webinar Perlu dilakukan secara rutin untuk meningkatkan pengetahuan mahasiswa kedokteran tingkat 3 UPNVJ. Melalui webinar mahasiswa akan dapat memiliki dasar ilmiah dalam mengetahui akibat stunting dan mencegah stunting pada masyarakat. Anak dibawah usia dua tahun sangat rentan tejadi stunting. Kondisi stunting yang terlambat disadari akan mengganggu perkembangan fisik dan kognitif anak, keterlambatan perkembangan mental, serta penurunan kualitas belajar di sekolah (Onis et al,2013). Anak dengan stunting juga menunjukan performa pendidikan yang lebih rendah, kemampuan verbal dan IQ rendah(Nahar et al, 2019).

Kekurangan nutrisi pada 1000 HPK dapat juga berpengaruh terhadap morbiditas, mortalitas, serta berhubungan dengan kinerja intelektual dan kesehatan anak secara keseluruhan pada masa remaja hingga dewasa (Kemenkes RI, 2017). Kekurangan mikronutrien pada ibu hamil akan mempengaruhi pertumbuhan dan perkembangan janin serta mempengaruhi masa depan 
janin menjadi manusia dengan kelainan pada bagian ginjal, fungsi kardiovaskular, pancreas dan fungsi paru-paru (Christian and Stewart, 2010).

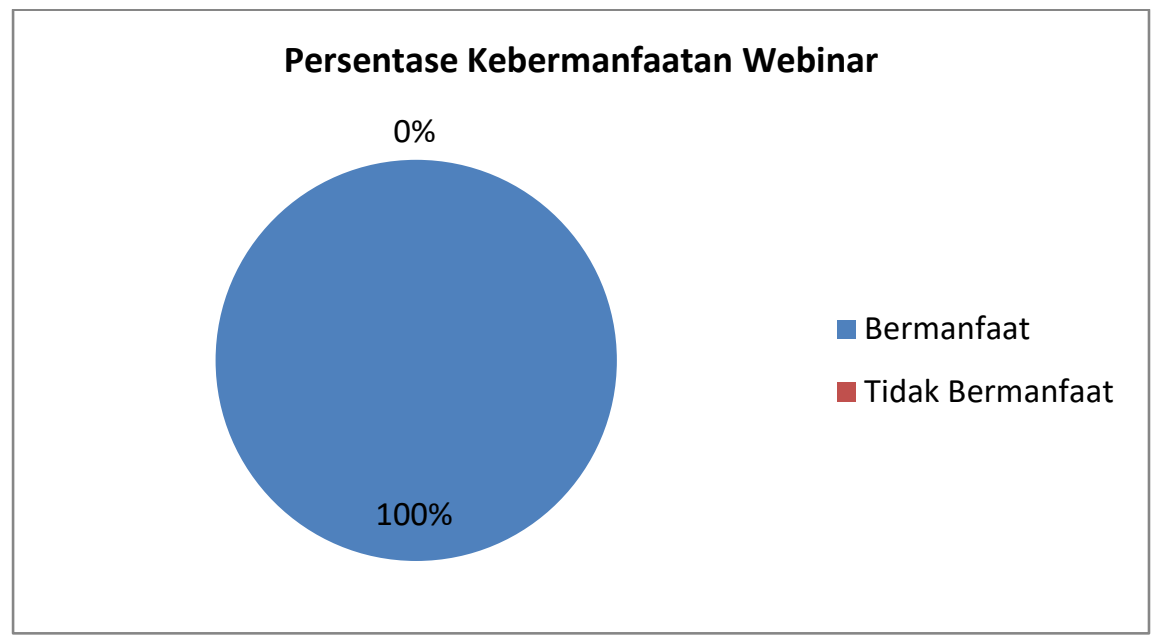

Gambar 3. Manfaat webinar

Pada gambar 4. mahasiswa kedokteran tinggkat 3 menyatakan webinar stunting perlu dilakukan jadi kegiatan rutinitas $98 \%$. Disini webinar sangat diperlukan untuk mencegah stunting.

Untuk mencegah stunting dalam mencapai pemenuhan nutrisi yang tepat $1000 \mathrm{HPK}$, perlu dilakukan Inisiasi Menyusui Dini (IMD) setelah bayi lahir minimal selama 1 jam. Berikan Air Susu Ibu (ASI) secara eksklusif dimulai sejak bayi lahir hingga bayi berusia 6 bulan. Pemberian Makanan Pendamping ASI (MPASI) sejak bayi berumur 6 hingga 24 bulan, dengan tetap melanjutkan pemberian ASI hingga anak berusia 24 bulan atau lebih (Kemenkes RI, 2018).

IMD dapat menstimulasi produksi ASI, menghasilkan antibodi bagi bayi baru lahir, mengurangi perdarahan pascapartum, dan menentukan keberhasilan pembentukan serta durasi yang lebih lama dalam menyusui. Penelitian menunjukkan bahwa IMD dikaitkan dengan risiko kematian neonatal yang lebih rendah (Takahashi et al., 2017).

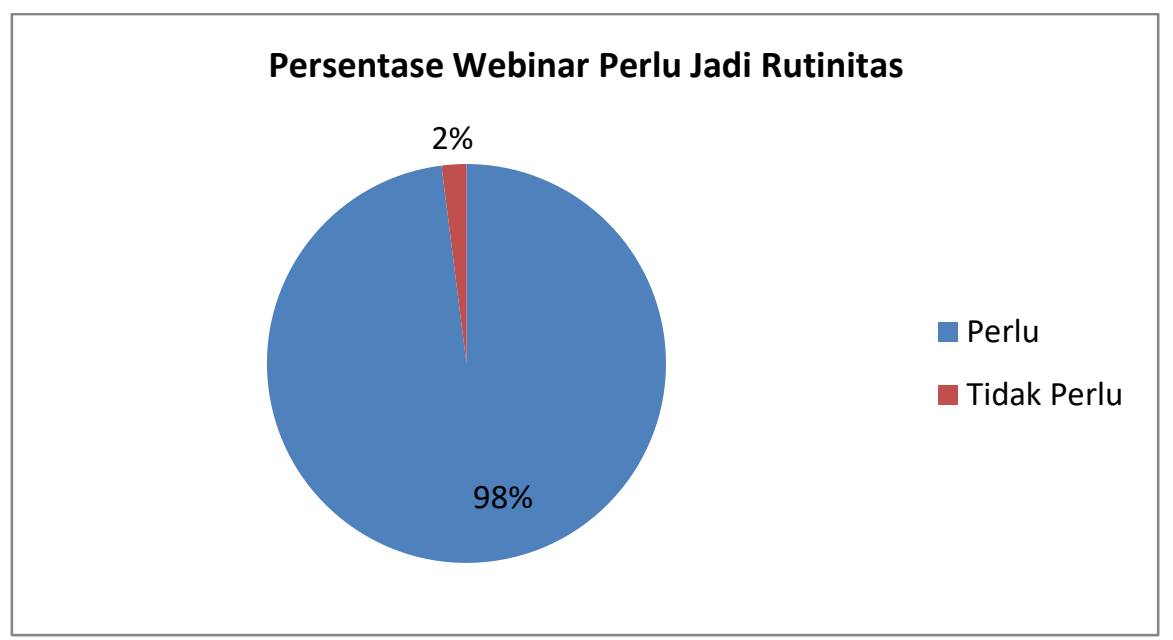

Gambar 4. Webinar perlu jadi kegiatan rutinitas

Pemberian ASI eksklusif juga terbukti mampu memenuhi kebutuhan nutrisi dan melindungi bayi dari berbagai penyakit infeksi seperti diare, gastroenteritis, infeksi saluran pernapasan akut bagian bawah, dan otitis media (Frank et al., 2019; NHS, 2020). Durasi pemberian ASI eksklusif 
mampu menurunkan prevalensi berat badan berlebih dan obesitas pada anak (WHO \& UNICEF, 2017).

Mahasiswa yang menyatakan tidak perlu diadakan Webinar\%tasenya $2 \%$. Hal ini munggkin disebabkan karena webinar dilakukan dalam rentang waktu yang cukup lama, mulai jam 8.30 13.00, yang dapat dilihat pada gambar 4.

Pretest mahasiswa kedokteran tingkat 3 dilakukan sebelum narasumber memberikan materi. Hasil pretest mahasiswa $78 \%$ yang dapat dilihat dari gambar 5 . di bawah ini.

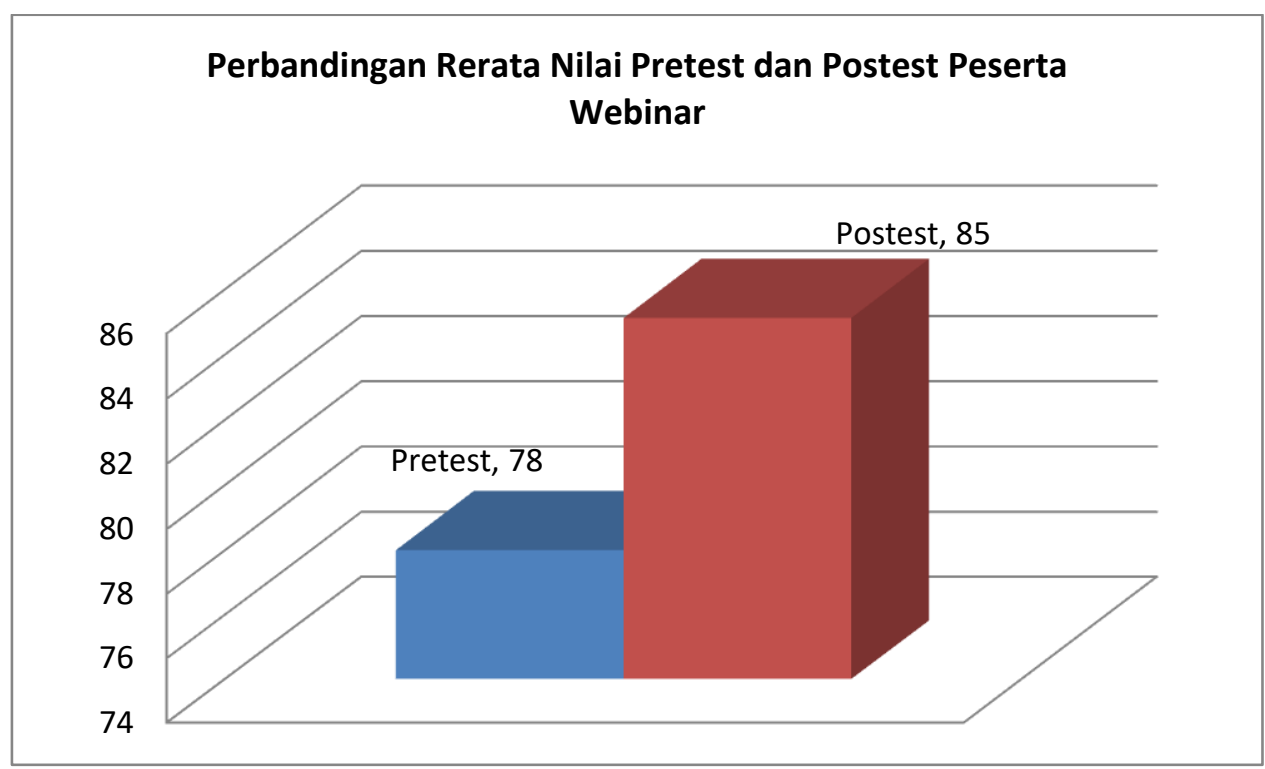

Gambar 5. Nilai Pretest dan posttest

Pada akhir acara webinar, mahasiswa diberi post test untuk mengetahui tingkat pemahaman mahasiswa setelah dilakukan webinar yang dapat dilihat pada gambar 5 . di atas. Hasil posttest mahasiswa meningkat, menandakan adanya peningkatan pengetahuan mahasiswa. Perlu pengetahuan mahasiswa dalam menyusun kebutuhan untuk pemenuhan gizi pasien. Juga pengetahuan tentang pola makan, pola asuh untuk mengetahui keluarannya setelah pasien mengonsumsi makanan tersebut. Untuk mendapat kan ketrampilan tersebut, maka mahasiswa harus mempunyai pengetahuan tentang bahan makanan sebagai sumber gizi makro atau mikronutrien, kejadian akibat kekurangan zat gizi makro-mikronutrien. Disamping harus tahu penggolongan makanan dan groupnya, maka mahasiswa harus mengetahui kebutuhan zat gizi pasien dan menyusunnya menjadi suatu makanan sebagai asupan sehat yang diperlukan untuk pasiennya.

\section{Kesimpulan.}

1. Webinar dilaksanakan 19 juli 2021 dengan 4 narasumber berjalan lancar. Narasumber merupakan dosen kedokteran UPNVJ yaitu dr. Adi Sukrisno,Sp.OG.FMAS., Dra.Arfiyanti,M.Kes, Dr.Nugrahayu Widyawardani, M.Gizi, SpGK., dr.Wendy, Sp.KK.M.Kes

2. Peserta webinar sebagian besar perempuan ( $81 \%$ ) dan $19 \%$ laki laki.

3. Webinar bermanfaat bagi mahasiswa kedokteran dan bisa dipraktekan di layanan kesehatan ibu dan anak sehingga bisa menekan kasus stunting nantinya. Kebermanfaatan webinar $100 \%$ 
4. Webinar Perlu dilakukan secara rutin (98\%) untuk meningkatkan pengetahuan mahasiswa kedokteran tingkat 3 UPNV]

5. Webinar dapat meningkatkan pengetahuan mahasiswa tingkat 3 kedokteran UPNVJ. Hasil pretest $(78 \%)$ dan posttest mahasiswa ( $85 \%)$.

\section{Daftar Pustaka}

Allen, 2012. B vitamins in breast milk: relative importance of maternal status and intake, and effects on infant status and function. Adv Nutr. 3:362-369.

Alvisi, P., Brusa, S., Alboresi, S., Amarri, S., Bottau, P., Cavagni, G., Corradini, B., Landi, L., Loroni, L., Marani, M., Osti, I., Povesi-Dascola, C., Caffarelli, C., Valeriani, L. and Agostoni, C. 2015. Recommendations on complementary feeding for healthy, full-term infants. Italian Journal of Pediatrics, 41(1).

Ballard $\mathrm{O}$ and Morrow AL.2013, Human milk composition: nutrients and bioactive factors. Pediatr Clin North Am.; 60(1): 49-74.

BAPPENAS, 2020. The Importance of the Golden Period of 1000 First Days for The Growth and Development of A Child [WWW Document]. URL https://cegahstunting.id/en/news/theimportance-of-the-golden-period-of-1000-first-days-for-the-growth-and-development-of-achild/

Beal, T., Tumilowicz, A., Sutrisna, A., Izwardy, D. and Neufeld, L. 2018. A review of child stunting determinants in Indonesia. Maternal \& Child Nutrition, 14(4), p.e12617.

Butts, C.A., Hedderley, D.I., Herath, T.D., Paturi, G., Glyn-Jones, S., Wiens, F., Stahl, B., Gopal, P., 2018. Human milk composition and dietary intakes of breastfeeding women of different ethnicity from the manawatu-wanganui region of New Zealand. Nutrients 10, 1-16. https://doi.org/10.3390/nu10091231

Campoy, C., Campos, D., Cerdó, T., Diéguez, E., Garciá-Santos, J.A., 2018. Complementary feeding in developed countries: The 3 Ws (When, what, and why?). Ann. Nutr. Metab. 73, 27-36. https://doi.org/10.1159/000490086

Castle, Paula. 2010. Omega -3 and Omega -6 Fatty Acid. United States: University of Nebraska Lincoln.

Christian P, Stewart CP.2010. Maternal micronutrient deficiency: fetal development and risk of chronic disease. J Nutr., 140:437-45.

De Onis, M., Dewey, K. G., Borghi, E., Onyango, A. W., Blössner, M., Daelmans, B., Piwoz, E. and Branca, F., 2013, The World Health Organization's global target for reducing childhood stunting by 2025: rationale and proposed actions, Maternal \& Child Nutrition;9: 6-26.

Dewey, 2016. Reducing stunting by improving maternal, infant and young child nutrition in regions such as South Asia: evidence, challenges and opportunities. Maternal and Child Nutrition.12(1): 27-38.

Fewtrell, M., Bronsky, J., Campoy, C., Domellöf, M., Embleton, N., Mis, N.F., Hojsak, I., Hulst, J.M., Indrio, F., Lapillonne, A., Molgaard, C., 2017. Complementary feeding: A position paper by the European Society for Paediatric Gastroenterology, Hepatology, and Nutrition (ESPGHAN) committee on nutrition. J. Pediatr. Gastroenterol. Nutr. 64, 119-132. https://doi.org/10.1097/MPG.0000000000001454

IDAI, 2015, Rekomendasi Praktik Pemberian Makan Berbasis Bukti pada Bayi dan Batita di Indonesia. Unit Kerja Koordinasi Nutrisi dan Penyakit Metabolik.

IDAI, 2018. Pemberian Makanan Pendamping Air Susu Ibu (MPASI). UKK Nutr. dan Penyakit Metab. IDAI.

Irfan, M., 2019. Complementary Feeding; Pros and Cons. Acta Sci. Nutr. Heal. 3, 12-16.

Jacqueline Kent, J. (2015). Breastfeeding Expectation. Infant Journal, [online] 11(3). Available at: http://www.infantjournal.co.uk/pdf/inf_063_cta.pdf [Accessed 15 Jul. 2019].

Ji Y, Wu Z, Dai Z, Wang X, Li J, Wang B, et al.2017, Fetal and neonatal programming of postnatal growth and feed efficiency in swine. Journal of Animal Science and Biotechnology.2017; 8: 42. 
Keikha et al, 2017, Macro- and micronutrients of human milk composition: Are they related to maternal diet? A comprehensive systematic review. Breastfeed. Med. 12, 517-527.

Kemenkes RI, 2017. Kualitas Manusia Ditentukan Pada 1000 Hari Pertama Kehidupannya [WWW Document]. URL https://www.kemkes.go.id/article/view/17012300003/kualitas-manusiaditentukan-pada-1000-hari-pertama-kehidupannya.html

Kemenkes RI, 2018. Praktik Pemberian Makanan Bayi dan Anak (PMBA) untuk Perubahan Perilaku Pemenuhan Asupan Gizi Anak dalam Upaya Pencegahan Stunting [WWW Document]. URL https://kesmas.kemkes.go.id/assets/upload/dir 60248a365b4ce1e/files/1PAPARANSTUNTING-DIR.GIZI 1222.pdf

Khomsan, 2004. Peranan pangan dan gizi untuk kualitas hidup. PT. Gramedia Widiasarana Indonesia. Jakarta.

Koletzko B.2016; Gardner et al, 2017.

Lestari et al, 2005. Nutritional status and nutrient intake from complementary foods among breastfed children in Purworejo District, Central Java, Indonesia. Paediatr Indones ; 45:31 $-9$

Marriott, B.P., Birt, D.F., Stallings, V.A., Ates, A.A., 2020. Present Knowledge in Nutrition, 11th ed, Nutrition Reviews. Elsevier. https://doi.org/10.1111/j.1753-4887.1998.tb01705.x

Millward, 2017. Nutrition, infection and stunting: the roles of deficiencies of individual nutrients and foods, and of inflammation, as determinants of reduced linear growth of children. Nutrition Research Reviews. 30(1):50-72.

Mosca, F., Giannì, M.L., 2017. Human milk: composition and health benefits. Pediatr. Med. Chir. 39, 155. https://doi.org/10.4081/pmc.2017.155

Nahar B., Hossain M., Mahfuz M., Islam M. M., Hossain M. I., Murray-Kolb L E, Seidman J C, Ahmed T., 2019, Early childhood development and stunting findings form MAL-ED birth cohort study in Bangladesh, Maternal \& Child Nutrition. e12864.

Perrella, S., Gridneva, Z., Lai, C.T., Stinson, L., George, A., Bilston-John, S., Geddes, D., 2021. Human milk composition promotes optimal infant growth, development and health. Semin. Perinatol. 45, 151380. https://doi.org/10.1016/j.semperi.2020.151380

Prendergast AJ, Humphrey $\mathrm{JH} ., 2014$, The stunting syndrome in developing countries, Paediatr Int Child Health, 2014; 34(4): 250-65.

Raymond, J.L., Morrow, K., 2020. Krause and Mahan's Food \& The Nutrition Care Process, 15th ed. Elsevier.

Sánchez, C., Franco, L., Regal, P., Lamas, A., Cepeda, A., Fente, C., 2021. Breast milk: A source of functional compounds with potential application in nutrition and therapy. Nutrients. https://doi.org/10.3390/nu13031026

Savarino, G., Corsello, A., Corsello, G., 2021. Macronutrient balance and micronutrient amounts through growth and development. Ital. J. Pediatr. https://doi.org/10.1186/s13052-02101061-0

Shah, R., Alhawaj, A.F., 2020. Physiology, Breast Milk, StatPearls. StatPearls Publishing.

Sjarif DR., Yuliarti K., Lestari ED., Sidiartha IGL., Nasar SS., Mexitalia M., 2015, Pedoman Ikatan Dokter Anak Indonesia. Unit Kerja Koordinasi Nutrisi dan Penyakit Metabolik Ikatan Dokter Anak Indonesia

Takahashi, K., Ganchimeg, T., Ota, E., Vogel, J.P., Souza, J.P., Laopaiboon, M., Castro, C.P., Jayaratne, K., Ortiz-Panozo, E., Lumbiganon, P., Mori, R., 2017. Prevalence of early initiation of breastfeeding and determinants of delayed initiation of breastfeeding: secondary analysis of the WHO Global Survey OPEN. https://doi.org/10.1038/srep44868

UNICEF, 2019. Evidence on the long-term effects of breastfeeding: Systematic reviews and metaanalysis [WWW Document]. URL https://www.unicef.org/media/60806/file/SOWC-2019.pdf

UNICEF, 2020. Improving Young Children 's Diets During the Complementary Feeding Period.

West, C., 2017. Introduction of Complementary Foods to Infants. Ann. Nutr. Metab. 70, 47-54. https://doi.org/10.1159/000457928

WHO \& UNICEF, 2017. Global Breastfeeding Scorecard 2017.

WHO, 2020. Complementary Feeding [WWW Document]. URL https://www.who.int/healthtopics/complementary-feeding\#tab=tab_1

Wild et al, 2015, Child stunting in developing countries. IARC Working Group. 
Young et al, 2018. Role of maternal preconception nutrition on offspring growth and risk of stunting across the first 1000 days in Vietnam: A prospective cohort study. PLoS One. 13:e020320 